\title{
A LOS ORÍGENES DEL PENSAMIENTO MEDIEVAL ESPAÑOL SOBRE LA HISTORIA: PRUDENCIO, OROSIO, SAN ISIDORO
}

\author{
Enrique Rivera de Ventosa \\ Universidad Pontificia de Salamanca
}

\begin{abstract}
RESUMEN
Los orígenes del pensamiento medieval hispánico arrancan de los escritores hispano-romanos: Prudencio, Orosio e Isidoro de Sevilla. Ellos son el punto de partida para una reflexión posterior sobre la historiografía hispánica de la Edad Media. Los tres presentan un cambio muy señalado de mentalidad. La perspectiva histórica no es igual en Prudencio que en Isidoro, siendo Orosio una especie de intermediario. Cada uno tiene una forma distinta de entender la historia. Por eso, creemos que es necesario conocer su mentalidad para penetrar en los entresijos de nuestra conciencia histórica.
\end{abstract}

Palabras clave: Prudencio, Orosio, Isidoro, Historia, Hispania.

\begin{abstract}
At the source of the Hispanic thougt about history: Prudencius, Orosius and Isidore of Seville. The source of the Hispanic Medieval thougt comes out from the Roman-Hispanic writters: Prudentius, Orosius and Isidore of Seville. They are the starting point for a subsequent reflexion of the Hispanic Historiography in the Middle Ages. The three writter present an important change of mentality. The historic perspective is not the same in Prudentius as it is in Isidore, while Orosius is rather intermediate. Everyone has sis own way to know their mentality in oder to penetrate into the secrets of our historic identity.
\end{abstract}

Key words: Prudencius, Orosius, Isidore, Hispania.

Nos limitamos en este estudio a los orígenes del pensamiento medieval español en torno a la historia, por ser el necesario punto de partida para una reflexión ulterior sobre la historiografía hispánica de la Edad Media. Los tres nombres mentados en el título incitan a penetrar en su pensamiento histórico por darse en ellos un cambio muy señalado de mentalidad. La perspectiva histórica es muy distinta en el primero y en el tercero, viniendo a hacer el segundo el oficio de intermediario. En verdad, cada uno de los tres nombres tiene un modo distinto de concebir la historia, algo que se nos hace imprescindible para penetrar en los entresijos de nuestra conciencia histórica. Ya algunas de nuestras grandes colecciones históricas abordan muy seriamente el tema. Pero es muy de notar que predomina en su reflexión el desarrollo de la vida civil hispana, sin tener suficiente- 
mente en cuenta las convicciones cristianas vigentes, de máximo influjo en el modo de contemplar la historia. ${ }^{1}$

Fecha decisiva para nuestra reflexión sobre Prudencio y Orosio juzgamos las dos décadas finales del siglo IV y las dos primeras del siglo V. Conceptuamos estos cuarenta años entre los más movidos de la historia de Occidente. Se da en ellos una patente aceleración de la historia. Las dos décadas finales del siglo IV viven en un momento imperial que tiene su plenitud en la figura del gran Teodosio, emperador hispano. Las dos prímeras décadas del siglo V son de enorme convulsión. En ellas tiene lugar la irrupción de los bárbaros, que atraviesan el Rin para inundar las provincias romanas de la Galia y de la Hispania. Por la Europa del sur culmina esta irrupción con el asalto de Roma por los godos de Alarico, el 24 de agosto de 410. Esta gran catástrofe -así juzgada entonces - tan al vivo hirió al solitario Belén, al Jerónimo de la Vulgata, que interrumpe sus comentarios al profeta Ezequiel para dolerse de la tragedia que está viviendo el mundo con este lenguaje desgarrador: «Me falta la voz y mientras estoy dictando, los suspiros interrumpen mis palabras... Cuando se apagó la luz más clara del universo y cayó la cabeza del mundo romano, enmudecí y quedé abatido . Esta misma convulsión motiva que san Agustín escriba su magnum opus en expresión suya - , sus ponderados libros De Civitate Dei. Sería cosa de preguntarse si el Agustín que escribe esta obra monumental en torno a la década de 420 es el mismo que, 33 años antes, desahogaba su alma ante Dios en sus inigualables Soliloquia. No es el momento de responder a esta pregunta. Pero sí de tomar conciencia de que Prudencio vive la plenitud imperial cristiana de los últimos años del siglo IV, años en los que tiene vigencia para él la «aurea Roma», mientras que Orosio, bajo el golpe de Alarico y el pesimismo de san Agustín, prospecta este Imperio romano como «perenne miseria histórica». En qué breve tiempo la historia de Roma cambia de sentido en la interpretación que se da de la misma. Esta diversa interpretación viene a ser, por otra parte, el punto de referencia de la visión de san Isidoro, muy distanciada de Prudencio por lo que toca a la misión del Imperio romano, y apoyado en Orosio al percibir la gran misión histórica de los nuevos pueblos y naciones que se están formando. Damos con esto el enfoque mental de nuestro triple momento reflexivo.

\section{PRUDENCIO: UNIVERSALISMO CRISTIANO E IMPERIAL}

Las dos últimas décadas del siglo IV en que vive Prudencio lo mejor de su vida destacan en la historia cristiana como un momento cumbre en el que se dan la mano el máximo poder de la tierra -imperium romanum - y el cristianismo en su función evangélica de levadura que hace fermentar los mejores valores de la gran cultura clásica. El representante más significantivo de este momento histórico - no el más amplio ni el más profundo- es sin duda san Ambrosio. Por heren-

1 Historia de España (dir. R. Menéndez Pidal), Madrid, Espasa-Calpe, 1940. T. III. España Visigoda. Introducción: Universalismo y nacionalismo. Romanos y germanos. (R. Menéndez Pidal), pp. VII-LV.

2 Commentariorum in Ezequielem Prophetam libri quatordecim. Lib. III (introd.). ML. 25. 75-76. 
cia y por formación se hallaba impregnado de un romanismo que puso al servicio del nuevo ideal cultural cristiano. Resumimos aquí lo que sobre el mismo hemos escrito en otra ocasión. ${ }^{3}$

Fue san Ambrosio constante en su elevado intento de poner al servicio de su incarnacionismo cristiano los altos valores de la cultura greco-romana. Desde la visión cristiana de la historia llama la atención su profundo sentido de continuidad entre ambas culturas. Su obra De officiis pone en gran relieve este sentido de continuidad. Entusiasma adentrarse por las fuentes de esta obra de san Ambrosio. Nos ponen éstas ante los ojos uno de los milagros más preclaros en nuestra vida del pensamiento. En efecto, como es sabido, san Ambrosio tiene ante sí al componer su obra la de Cicerón, que tiene el mismo título. Éste, a su vez, cita reiteradamente a Panecio, con el que declara tener deuda. Es, pues, este filósofo del estoicismo medio el punto de partida de esas reflexiones sobre la vida diaria que, expuestas en los libros De officiis, llegan hasta nuestros días. Educado Panecio en el estoicismo clásico, renuncia a las especulaciones metafísicas del mismo y se atiene a lo que exige el deber diario, lo conveniente de cada hora. Cicerón, con corazón de padre, piensa que a su hijo Marco le servirá de orientación una obra con este título: De officiis. La escribe y se la dedica. Empalma san Ambrosio con Cicerón y se dirige a sus clérigos, también con el corazón en la mano, para aconsejarlos como padre. Indudablemente, corren por estas obras de los diversos pensadores los mismos aires de alta y humana espiritualidad. Y no hace falta decir que ello no perjudicaba en nada a la moral evangélica. San Ambrosio envolvía sencilla y eficazmente su pleno cristianismo en los límpidos pañales de la gran cultura clásica. Le será siempre de gloria perenne el haber «encarnado» la moral profesional cristiana en el marco de la filosofía estoica. Y esto llega hasta nosotros. Qué magnífica continuidad del espíritu humano constatamos en este avatar filosófico de siglos: del griego de Rodas, Panecio, al romano Cicerón; de éste a san Ambrosio. Y por éste, a los moralistas cristianos que tan detenidamente han venido estudiando hasta nuestos días la moral profesional, que tiene un momento cumbre en la Summa Theologica de santo Tomás, II-Ii, quaestiones 183-189: «De officiis et statibus hominum».

En este ambiente de plenitud política y cultural vive Prudencio, pero con un entusiasmo por el universalismo imperial de Roma que no advertimos en el romanizado Ambrosio. «Aurea Roma» se complace en llamar a la gran ciudad. Y en otras ocasiones le da estos encomios: «Saeculi summum caput». «Egregium caput orbis». ${ }^{4}$

Una pregunta pudiéramos dirigir a Prudencio después de oírle los encomios que brinda a Roma. ¿A qué debió ésta la grandeza de su universalismo imperial? La pregunta es tan compro-

3 E. Rivera de Ventosa, «Visión cristiana de la historia y otros textos». Anthropos, Suplementos 26, p. 47.

4 Obras completas de Aurelio Prudencio. Edic. bilingüe. Versión esp. de A. Ortega; introd. comentarios, índices y bibliografía de I. Rodríguez. Madrid, BAC, 1981. Las citas del texto en: Apotheosis, v. 385, p. 204; Peristephanaon. Hymnus 10. Romanus, v. 167, p. 636. (Citaremos siempre por esta autorizada edición. Como bibliografía complementaria de nuestro estudio indicamos las obras siguientes: L. Riber, «El españolismo de Aurelio Prudencio» Acción Española, (enero 1935), p. 32-56. Ídem, Aurelio Prudencio, Barcelona, Labor, 1936; R. García Villoslada, «Los orígenes del patriotismo español. El primer canto a España», Razón y $F e, 116$ (1939), p. 381-402; I. Rodríguez Herrera, «Prudencio, poeta de la Hispanidad», Helmántica, 1 (1950), pp. 85-101; J. Pedraz, «Filosofía de la Historia del Imperio Romano en los poemas de Prudencio», Helmántica 2 (1950), pp. 182-191. 
metida que motivó el que san Agustín tomara la pluma para escribir su máxima obra: De Civitate Dei.

Los paganos atribuían la grandeza de Roma a sus dioses, que la abandonaron al ser expulsados por los cristianos. A refutar esta imputación va dirigida la obra mentada de San Agustín. Los cristianos, por su parte, vieron en la historia de Roma un plan providencial de Dios para preparar las vías universalistas del Evangelio. Rechazaron con decisón la pagana ayuda de los dioses a la ciudad. Pero, ante la cuestión de si las virtudes de Roma contribuyeron al florecimiento de su historia, los catastróficos sucesos de las primeras décadas del siglo $\mathrm{V}$ les hicieron ver estas virtudes con signo negativo. Se ha probado ser inauténtica la frase de san Agustín al calificar estas virtudes de «splendida vitia». Pero mútiples sentencias agustinianas dan sobrado motivo para atribuirle la famosa frase. San Agustín peca indudablemente de pesimista ante las supuestas virtudes de Roma.

Algo muy distinto tenemos que decir de Prudencio. Su estusiasmo ante el carácter romano y la actuación viril de sus virtudes empareja con lo que leemos en el gran poema de Virgilio, canto a los orígenes y a la grandeza de Roma. Nos atrevemos, sin embargo, a decir que si el entusiasmo virgiliano por el destino de Roma no tiene parigual, tampoco lo tienen los argénteos versos en los que Prudencio canta de dónde le vinieron sus grandes y triunfales victorias. Pone estos versos en labios de los hijos de Teodosio, Arcadio y Honorio. Responden con ellos al senador Símaco, quien pedía volviese al senado la estatua de la Victoria, a quien, según él, debía Roma su grandeza. Los dos príncipes hermanos convinieron con Símaco que a Roma le fue la victoria muy dulce. Pero, sobre el modo de lograrla, de niños lo aprendieron de su padre, quien, a su vez lo aprendió del suyo. Ésta fue la lección, herencia de la familia imperial. Ni los ruegos ante las aras, ni la harina de la tarta sagrada han tenido que ver en las victorias de Roma. Fueron causa de las mismas las siete virtudes que señala aquí el entusiasta poeta. Las acotamos en su expresivo asyndeton original: «Labor impiger, aspera virtus, vis animi excellens, ardor, violentia, cura, durum tractandis robur in armis».5 Difícil de hallar un encomio más recio y potente a las virtudes romanas. Ante su conciencia cristiana, Prudencio no suscita el quisquilloso problema de si eran virtudes en sentido estricto estas virtudes naturales. No entraba de lleno en su propósito. Tampoco en el nuestro, al comentar ahora el cálido entusiasmo de Prudencio por los altos valores que la «aurea Roma» contenía dentro de sí.

En un paso ulterior se entusiasma Prudencio por la unificante faena de Roma, de tanto influjo histórico en el pensar y en el vivir hispanos. Se ha de advertir que, nacido Prudencio en el valle del Ebro, se siente muy enraizado en su Hispania, con un cálido amor a su patria chica. Pero este su amor a la propia tierra no mermó su entusiasmo ante la obra de unificación de pueblos realizada por Roma. En dos momentos muy señalados canta Prudencio este histórico tema. Detengámonos a regustar de estos dos cantos.

El primero lo leemos en su poema al mártir español san Lorenzo. Después de reír lo que Lorenzo en plan de chascarrillo - ludibundus - dijo al tirano sobre comer su carne cruda o asada, relata Prudencio cómo se vuelve a Cristo el mártir para decirle: «iOh Cristo, nombre único, crea-

5 He aquí la traducción de estos versos dada en la ed. cit. de la BAC: «El esfuerzo infatigable, el rudo coraje, la alta energía del espíritu, el ardor, la impetuosidad, el afán, la dura fortaleza en el manejo de las armas». Se halla el texto en Contra Symmachum, lib. II, v. 24-26. 
dor del mundo y de los cielos, fuerza del padre! Fundador también de estas murallas de Roma, a la que colocaste en la cima del mundo, para que se rindiera la fuerza de sus armas. Ved cómo todo el género humano se sometió al reino de Remo». Cierra Prudencio este momento de su canto con estos dos versos que, por su proyección histórica hasta nuestros días, damos en su texto original: «Idem loquuntur dissoni ritus, id ipsum sentiunt» («pueblos discordantes hablan la misma lengua con iguales sentimientos»). ${ }^{6}$

Todavía canta con mayor detención la unión de pueblos y naciones realizada por Roma en su alegato contra el ya citado senador Símaco. Ve Prudencio en este segundo momento la que más tarde se llamará «pax romana» hasta nuestros días. La furiosa Belona, diosa de la guerra, confundía todas las cosas humanas y armaba las manos feroces, lamenta Prudencio. Pero Dios dispone contra ella un plan providencial. He aquí cómo lo describe el gran poeta:

Para frenar esta locura enseñó Dios a las naciones venidas de todas partes a inclinar su cabeza bajo las mismas leyes y a que se hiciesen romanos aquellos a quienes baña el Rin y el Danubio, el aurífero Tajo y el caudaloso Ebro [...]. Una ley común los hizo iguales y unió bajo un mismo nombre, y, dominados, los unió en fraternos lazos [...]. Regiones muy distantes y litorales divididos por el mar se unen, ora por obligación de comparecer ante un mismo tribunal, ora por el comercio y las artes [...]. ${ }^{7}$

Suspendemos aquí la cita para unirnos a este canto a la unidad de lo que más tarde se llamará la «romanía». No es que un burdo centralismo autorice a ver en la cuenca del Mediterráneo el centro de la cultura humana, como si esta cultura fuera única y modélica. Pero sí es para afirmar y reafirmar que ha dado una aportación primaria a la cultura humana. Y por humana, universal.

Este suspense está también motivado porque a continuación, Prudencio tiene que entusiasmar a todo espíritu reflexivo. El porqué de esta afirmación se funda en el dicho reiterado en el último medio siglo: la mayor desgracia de la trabajada historia que hemos vivido ha sido la malhadada idea racista que a tantos hombres ha llevado a un holocausto cruel y sin sentido. Pues bien, en estos versos que acotamos a Prudencio, después de cantar la unidad romana de la concordia de pueblos, da una eterna repulsa a la monstruosa y sanguinaria concepción racista:

[...] nam sanguine misto

texitur alternis ex gentibus una propago.

Traducimos estos inmaculados versos históricos dentro del contexto interrumpido por el suspense:

[...] y se unen los diversos países por el lecho nupcial, al ejercer el derecho de un matrimonio con un extranjero, pues, entremezclada la sangre, se trenza, de naciones diferentes, una sola descendencia. ${ }^{8}$

6 Peristephanon. Hymnus 2. Passio Laurentii beatissimi martyris, v. 413-428, p. 514-516.

7 Contra Symmachum, lib. II, v. 598-615, p. 446.

8 Ibídem, v. 616-618, p. 446. 
Será perenne gloria moral de la Hispania histórica el que hace más de mil seiscientos años su máximo poeta latino dio para siempre eterno repudio a la nefasta e inhumana concepción racista. El amor a sus tierras del Ebro, a las que tanto pondera, no fue obstáculo a que se abriera a los otros pueblos con los que la Hispania debía mantener su unidad bajo el imperio cultural de la «aurea Roma». Indudablemente, un firme universalismo imperial tenía ante sí el espíritu del gran poeta hispano. Y no sólo lo aceptó, sino que lo amó.

Para completar el pensamiento de Prudencio, es menester añadir que en el universalismo cultural de Roma vio el poeta un anticipo del universalismo cristiano. Mejor fuera decir, una «preparatio evangelica», según la fórmula acuñada medio siglo antes por Eusebio de Cesárea. También este tema lo tiene muy presente en su himno a san Lorenzo y en la refurción de Símaco. Resumimos aquí lo mejor de estos dos excelsos momentos.

En el himno a san Lorenzo, después de resaltar la unión de pueblos y naciones bajo las leyes de Roma canta: «Así se decretó para que la ley del cristianismo uniera en un único lazo cuanto existe por cuanto la tierra abarca». Ante esta perspectiva de la historia, dirige a Cristo, que la preside, esta ardietne petición: «Concede, Cristo, a tus romanos que sea cristiana la ciudad por la que diste un mismo sentido religioso a todos los pueblos. Que de una parte y de otra todos sus miembros se unan en una profesión de fe». ${ }^{9}$ Con estas palabras, escritas en cálido verso latino, Prudencio vincula en su entusiasmo religioso ambos universalismos: el romano del derecho imperial y el cristiano de la nueva fe. Complemento de ambos considera esta presente y futura realidad: «El orbe sometido se dulcifica y la cabeza soberana se irá haciendo más mansa». ${ }^{10}$ Apena que perspectivas tan rientes de paz humana y cristiana no llegaran a cumplirse. En el atardecer de su vida Prudencio ya pudo entrever que la historia de Roma tomaba derroteros muy distintos y nada halagüeños. Pero señaló para siempre una meta a las mejores aspiraciones humanas y cristianas.

En su impugnación de las pretensiones de Símaco desarrolla el mismo tema de modo más detenido. Encarándose con el romano le muestra el último porqué de las grandezas de su ciudad en estas aserciones, dichas con elevado estro poético: ${ }^{11}$

Queriendo Dios asociar a los pueblos de diversas lenguas y a los reinos de cultura diferente, determinó someter a un solo imperio las naciones de civilizadas costumbres y hacerlas llevar unos lazos suaves bajo el mando de la concordia [...]. Para Cristo, que ya entonces llegaba, créelo, fue preparado el camino que por largo tiempo construyó la amistad pública de nuestra paz bajo la dirección de Roma.

Después de esta gráfica descripción de la paz romana, el poeta se dirige a Cristo para pedirle:

Ven, Omnipotente; desciende a la tierra que está en concordia. Ya te recibe, joh Cristo!, el mundo a quien mantienen en apretado nudo la paz y Roma. Ambas ordenas Tú que sean

9 Passio Laurentii, v. 429-438.

10 Ibídem, v. 439-440, p. 516.

11 Contra Symmachum, lib. II, v. 586-590; 620-622, p. 446. 
cabeza de cumbre del universo. No halla Roma sin paz favor en ti. Y que la paz logre tu complacencia es obra excelsa de Roma, pues pone freno a las diversas sediciones. ${ }^{12}$

De seguro, esta unión, ya más que armonía de poderes, disgusta hoy ante los ingentes abusos de una y otra parte que la historia fáctica nos relata. Pero el gran poeta hispano canta lo que idealmente entrevé: la unión de los mejores esfuerzos de la tierra para hacer más posible el triunfo de la concordia y de la paz bajo el signo cristiano. Y no es que confundiera lo debido al César y a Dios. En su canto a san Emeterio y Celedonio, militares al servicio del César, nos hace oír este límpido verso, que abre la descripción de su martirio: «Tempus est Deo rependi quidquid est propium Dei» («Ahora es el tiempo de dar a Dios lo que es de Dios»). ${ }^{13}$

En el martirio de san Lorenzo pone el poeta en labios del tirano el dicho de Jesús: «Dad al César...». Por lo mismo exige a Lorenzo que le enseñe los tesoros de la Iglesia que llevan en sus monedas la efigie del César. Como es sabido, Lorenzo, en vez de coleccionar monedas de oro y plata, presenta al tirano los pobres de la Iglesia, los menesterosos que tienden su mano a la limosna. Anécdota tan simpática no quita valor al criterio del poeta sobre la distinción de poderes, si bien desea que en la historia luchen conjuntamente contra las fuerzas del mal. Este ideal político-religioso de Prudencio ha tenido éxito muy menguado en la historia. Pero ello no resta fuerza a este excelso ideal dentro de un ejemplar gobierno del mundo.

Este esquema mental, extraído de la poemática de Prudencio, hace patente su universalismo: el imperial de Roma y el religioso cristiano. Con todo, nos sale al paso en este momento final una cuestión de trasfondo que por su importancia no podemos dejar al margen. Versa en torno a la refutación que el poeta hace del intento de Símaco a favor de la diosa Victoria. Una anécdota muy actual pone la vieja cuestión al rojo vivo.

El XIV Congreso Internacional de Filosofía en Viena, primeros días de septiembre de 1968, celebró su solemne apertura en el suntuoso teatro de la Ópera. Entre los altos dignatarios presentes se hallaba el Card. F. König. Pronunció el discurso inaugural el conocido filósofo H.-G. Gadamer. Al final del mismo recordó cómo el senador romano Símaco, dirigiéndose a la religión que en aquel momento ascendía, pronunció esta sentencia contra toda clase de dogmatismo: «Uno itinere non potet pervenire ad tam grande secretum». ${ }^{14}$ Qué coincidencia y qué contraste al advertir que esta misma sentencia es la que Prudencio tiene más presente al refutar al senador romano. Y es de notar que ambos, Prudencio y Gadamer, acuerdan en considerar el tema un gran misterio humano: «grande secretum», para Gadamer; «grande profundum», para Prudencio.

Pero si Gadamer, evocando a Símaco, niega que haya un solo camino para desvelarlo, Prudencio afirma decididamente lo contrario en estos dos versos que, por su proyección histórica, citamos en su pulcritud original:

12 Ibídem, v. 634-640. p. 448.

13 Peristephanon. I. Hymnus in honorem sanctorum martyrum Emeterii et Celedonii Calagurritanorum, v. 61-63, p. 484.

14 H.-G. Gadamer, «Über die Macht der Vernunft», en Akten des XIV Internat. Kongresses fiirPhilosophie. VI. Öffentliche Vorträege, Universidad de Viena, 1971, p. 38. 
Sola errore caret simplex via nescia flecti in diverticulum biviis ne pluribus anceps. ${ }^{15}$

Una crítica serena tiene que estar con Prudencio contra el intento pluralista de la verdad defendido por Gadamer. Pero se ha de advertir que Prudencio, al proponer a Cristo como única vía hacia la verdad, tenía ante sí un burdo politeísmo que hacía casi inviable el acceso a Dios. Ha sido, con todo, un desacierto que desde los tiempos de Prudencio - y aun antes - se haya visto en la idolatría la encarnación del espíritu del mal. Por el contrario, san Pablo vio en el Dios desconocido, al que adoraban los atenienses, y en el razonamiento de sus pensadores, tanteos valiosos por llegar a palpar a Dios. Esta mentalidad apostólica, olvidada por largo tiempo, hoy vuelve a sentirse después del Vaticano II. Y en los tanteos de que habla el apóstol es muy posible que los cristianos puedan tender su mano a muchos hombres de buena voluntad que sinceramente buscan a Dios.

Hemos comentado este aspecto negativo del universalismo de Prudencio para sentir con mayor relieve los esfuerzos que va realizando la mente cristiana en la conquista de la verdad, que sólo en el más allá se nos dará en plenitud.

\section{OROSIO: UNIVERSALISMO CRISTIANO Y NACIONALISMO PRESENTIDO}

La mejor presentación del escritor hispano Pablo Orosio la hace san Agustín en carta recomendaticia a san Jerónimo, para que éste lo acogiera en Belén. Huyendo de los bárbaros que en la primera década del siglo $\mathrm{V}$ irrumpieron en España y preocupado además por cuestiones doctrinales, Orosio se siente atraído por el oráculo doctrinal de aquel momento histórico, san Agustín. Va a visitarlo a Hipona, camino de Palestina, y da tan buena estampa al experimentado doctor que éste escribe a san Jerónimo en estos términos: «Vino a mí un joven de sentido religioso, hermano en la paz católica, despierto de ingenio, pronto en palabras, preocupado por el estudio y deseoso de ser un vaso útil en la casa del Señor, para refutar las doctrinas perniciosas que han despedazado las almas de los hispanos mucho más infelizmente que la espada de los bárbaros lo han hecho con sus cuerpos». ${ }^{16} \mathrm{~A}$ su retorno de Palestina, cuenta él mismo cómo en conversación con san Agustín, éste le propuso que escribiera contra la petulante maldad de aquellos que, alejados de la Ciudad de Dios, paganos o gentiles, proclamaban que los males actuales eran los peores que se habían sufrido debido a que se creía en Cristo y se daba culto a Dios, al mismo tiempo que se abandonaban los dioses protectores de Roma. Esto motivó que Orosio se pusiera a escribir y que en dos años, 415-416, compusiera su obra: Historiarum libri septem contra paganos. ${ }^{17}$ Es en verdad su obra más importante. En los primeros siglos de la Edad Media vino a ser una especie de manual de historia.

15 Contra Symmachum, lib. II, v. 849-850, p. 460. Traducción de los dos versos citados: «Sólo carece de error la vía derecha que no sabe torcer hacia otras sendas y no motiva dudas con sus múlplices bifurcaciones».

16 S. Agustini epistola 166, 2. Pl., XXXI, 720.

17 Puli Orosii Historiarum libri septem (contra paganos). P1., XXXI, col. 603-1174. 
Ha sido posible precisar la fecha de su composición porque el mismo Orosio refiere que, cuando san Agustín le dio el encargo de componerla, terminaba éste de publicar los diez primeros libros de su $D e$ Civitate Dei, de los que dice ser «orientes radii», que iluminan la Iglesia. El gran doctor estaba redactando el libro XI en la fecha que hemos señalado para la obra de Orosio, la cual debía completar, en intención de san Agustín, su relato histórico de los libros XV-XVIII. ¿Influyó Orosio en estos relatos o fue influido por san Agustín? Es obvio que se ha dado un influjo mutuo. ${ }^{18}$ Pero más importante que determinar este influjo, menester es subrayar que ambos tenían las mismas ideas directrices en la interpretación de la historia. Estas tres dan el nervio a la presente interpretación.

La primera es la proclamación de la Providencia divina como máximo agente de la historia. Éste dirige la historia según un plan eterno que se ha de cumplir contra las rebeldías humanas. Ambos tienen presente la profecía de Daniel sobre la sucesión de cuatro imperios. Con todo, si san Agustín acepta la común interpretación dada entonces a los mismos, Orosio señala al cartaginés como tercer imperio después del babilonio y del macedónico y antes que el romano, al que todavía tienen uno y otro por perenne, pese a los embates que le hacían bambolear en aquel mismo momento histórico.

La segunda idea de ambos sobre la historia consistía en juzgar que los grandes males que se constatan en ella son siempre debidos al pecado. Textualmente escribe Orosio: «Los males de la historia que han tenido lugar, como igualmente los que ahora son, lo son indudablemente, o por ser pecados en sí mismos, o por ser castigos ocultos por los pecados». ${ }^{19}$

La tercera idea fue un extremo pesimismo, que ha impregnado a lo largo de los siglos a una parte de la historiografía cristiana de signo piadoso. Ésta fuera de dudas que los dos pensadores cristianos estaban abiertos a ese fundamental optimismo, inherente a una visión providencialista de la historia. Pero, ciertamente, pasan la raya al exagerar su descripción de las miserias humanas. Disculpa esta preferencia la necia crítica de los paganos, al afirmar que los tiempos pasados fueron mejores para Roma por la protección que recibieron de sus dioses. A esta calumnia quisieron herirla en la cabeza. Pero se excedieron en hacer resaltar los aspectos negros del pasado. Baste mentar el juicio que Orosio emite sobre Alejandro Magno. No es cosa defender sus muchos desmanes. Pero tampoco hay que olvidar que la idea del ecumenismo - oikouméne-, hoy tan fecunda, se la debamos a Alejandro, quien levantó bandera y acción en pro de tan prometedora realidad, hoy ante nosotros en viva perspectiva. A su vez, en Roma ve tanta miseria que le da el título de «Roma misera». Si recuerda a la familia egregia de los Flavios, que lo dan todo por la patria, es para hacer sentir mejor la situación de Roma después de la retirada de los galos: «toda la ciudad hecha un suspiro por los enfermos o por los muertos». ${ }^{20}$

Cuanto llevamos dicho nos facilita el acceso a lo más íntimo del pensamiento de Orosio sobre la historia. Gozne de este su pensamiento es su universalismo cristiano. En dos pasajes de su

$18 C f$. J. Vaz de Carvalho, «Dependerá S. Agostinho de Paulo Orosio?», Revista Portuguesa de Filosofía, XI, I (1955), 142-153.

19 Historiarum lib. I, cap. I, col. 671.

20 Historiarum lib. III, cap. 21, col. 842. 
Historia se detiene a exponer dicho universalismo, tanto por lo que toca a su origen y fundamentación en Cristo cuanto desde su vivencia personal.

Con morosa delectación y acusado lirismo describe Orosio el origen del universalismo cristiano. Brevemente lo resumimos. Consta como indudable, escribe Orosio, que el primer César Augusto, después de hacer la paz con los partos, la extendió a toda la tierra, obligando a deponer las armas y a eliminar las discordias. Entonces llegan todos a regirse por las mismas leyes romanas y prefieren en sus tribunales jueces romanos. Una sola voluntad aúna todas las gentes, todas las provincias, pueblos infinitos, incontables países. Si todo esto acaece imperando César Augusto, durante este mismo imperio comienza a lucir nuestro Señor Jesucristo. Hasta los que blasfemaban contra él se vieron forzados a reconocer que esta paz del mundo entero y la serena tranquilidad de que se disfrutaba no se debía a las grandes obras del César, sino al poder del Hijo de Dios que se mostró en su tiempo. Éste ya no es sólo el emperador de la gran Urbe (Roma) sino el creador de todo el universo. Como el sol nace por el Oriente y disipa toda tiniebla, así vino Cristo misericordiosamente para vestir con su paz al mundo entero». ${ }^{21}$

Debemos leer en este pasaje de Orosio un himno al universalismo cristiano, mentalidad vigente en los tres primeros siglos de persecución, pero ahora proclamado contra mezquinas estrecheces dentro de la misma Iglesia. En su estancia en África, Orosio pudo sentir muy de cerca una de ellas, el donatismo. San Agustín lo combatió reciamente con sus escritos y con su acción. Orosio, sin nombrarlo, nos da en el pasaje que hemos resumido una preclara refutación del mismo. En verdad, la mente de Orosio se hallaba aireada por el viento de Pentecostés, abierto a todos los pueblos y naciones, al ponerse en marcha a lo largo de los siglos.

Tenemos ahora que añadir que este universalismo Orosio lo vivió muy intensamente como nota peculiar de su vida. Nos lo hace ver en el segundo texto aludido, en que parece poner en nuestras manos su corazón. Nos dice en dicho pasaje que ante el hecho de haber tenido que huir de una parte para otra, se ha sentido, sin embargo, seguro por doquier por esta razón que le confortaba:

Ubique patria, ubique lex et religio meta est. ${ }^{22}$

De este que pudiéramos llamar su lema vital hace el siguiente comentario: «Ahora me encuentro en África, que me recibió tan amablemente como confiadamente me llegué a ella. La latitud del oriente, la amplitud septentrional, la difusión del mediodía, las grandes islas, todo viene a ser para mí morada segura. Sólo Dios, que me ha manifestado cuando ha querido y ha establecido esta unidad, es amado y temido por todos. Las mismas leyes, conformes con los preceptos divinos, están vigentes por doquier. Así son de buenos nuestros tiempos. En seguridad y tranquilidad, en esperanza de bien y seguridad para todos, nunca los hubo mejores». ${ }^{23}$

21 Historiarum lib. III, cap. 8, col. 812.

22 Historiarum lib. V, cap. 2, col. 921.

23 Ibídem, col. 922. Siente con entusiasmo esta vertiente del tema Diamantino Martins, «Paulo Orósio. Sentido universalista da sua vida e da sua obra», Revista Portuguesa de Filosofía, XI, II (1955), pp. 375-384. 
Más de uno podrá leer en estas líneas entusiastas un contraste con el pesimismo histórico de Orosio, que hemos comentado. Pero ya se indicó que un pensador cristiano tiene siempre en su mente una perspectiva brillante de optimismo. En un mundo lleno de miserias, que Orosio describió de modo truculento no pocas veces, él ve alzarse la luz de Cristo en la historia. Esta luz ilumina plenamente su universalismo cristiano, el cual, ayer y hoy, ha tenido siempre un sentido optimista de cara al mucho mal que hay que combatir hasta vencer. En días amargos y para temblar Orosio tuvo la serenidad cristiana de vivirlo intensamente.

Como es muy sabido, se daba entonces otro universalismo: el del Imperio romano. Durante los cuatro primeros siglos de la Iglesia, en los tres de persecución y en el cuarto de triunfo constantiniano, los cristianos daban por supuesta la permanencia de este universalismo. Mas, ya comentamos el estremecimiento de san Jerónimo ante el saqueo de Roma por Alarico en 410. Le pareció el principio del fin. Pero Orosio, que escribe unos años después no está ya bajo la impresión de San Jerónimo. Un hecho, no comentado suficientemente, muestra el correr vertiginoso de estos años. Acabamos de decir que en 410 Alarico saquea Roma. Ello no es obstáculo para que cuatro años más tarde Placidia, hija de Teodosio y hermana de Honorio, emperador cuando el saqueo de Roma, case con el sucesor de Alarico en el mando de los godos, Ataúlfo. ¿Qué significación tuvo para Orosio esta boda que pudo haber cambiado la suerte del mundo, si el fruto de la misma, Teodosio, del mismo nombre que su abuelo materno, no hubiera muerto muy de niño? Ciertamente, que el mundo cambió mucho en pocos años. Este cambio lo refleja la obra de Orosio. Baste decir que vio en la boda mentada una ayuda muy eficaz para Roma - «molto reipublicae commodo fuit». ${ }^{24}$

Si contraponemos ahora el título de metal noble dado a Roma por Prudencio, al llamarla «aurea Roma», con el que le da Orosio reiteradamente, «misera Roma», se nos hace sensible la divergencia mental de estos dos grandes hispanos, en menos de veinte años, ante el destino de la Urbe. Orosio percibe claramente que Roma declina. Y también que nuevos pueblos, plenos de vigor, irrumpen en la historia frente a Roma o en colaboración con ella. De esta su nueva perspectiva deja constancia en un pasaje muy para ser meditado. Por su importancia lo citamos textualmente traducido. Viene escribiendo de la obra evangelizadora entre los bárbaros. Sus efectos los comenta así:

\footnotetext{
Después de esto, los bárbaros continuamente execraban sus espadas y se volvían a los arados. A los romanos que quedaron los trataron como socios y amigos, de tal suerte que ya muchos de ellos preferían gozar de una libertad en pobreza con los bárbaros que tener que soportar con los romanos los impuestos tributarios. ${ }^{25}$
}

Ante este pasaje, el historiador advierte que asoma por el horizonte el signo de lo que más tarde se llamará nacionalismo. Orosio no quiere romper con Roma. Pero presiente que su misión imperial parcialmente ha concluido. Nuevas fuerzas entran en la historia. Estas fuerzas son los pueblos llamados entonces bárbaros, los cuales vendrán a ser el núcleo de las futuras naciones de la historia. Orosio percibía esto en lontananza. Por eso podemos decir de él que su mente vivía ya un nacionalismo presentido. 
A mi juicio, tiene este nacionalismo presentido una larga página en la Historia de Orosio: el último capítulo de la misma. En él relata la historia de los tres primeros reyes godos, cuyos nombres aprendimos en las primeras lecciones de Historia de España: Ataúlfo, Sigerico, Valia. En Ataúlfo se detiene para subrayar que, después de su matrimonio con Placidia, se exaltó su pretensión política hasta intentar el cambio de la Romania en Gothia. Al experimentar lo imposible de su intento, permanece en defensa del imperio de Roma. Es su sucesor Valia, que manda sobre los godos desde 415 a 420, el que realiza ya la autonomía goda. Con este rey cierra Orosio su Historia.

En perspectiva histórica este último capítulo de la Historia de Orosio, que acabamos de comentar, se da la mano con la Historia de regibus gothorum, de san Isidoro. En estas dos historias advertimos el tránsito entre un nacionalismo presentido, el de Orosio, a un nacionalismo consciente, el de san Isidoro. Sobre éste pasamos a reflexionar ahora en el tercer momento de nuestro estudio.

\section{SAN ISIDORO: UNIVERSALISMO CRISTIANO-NACIONALISMO CONSCIENTE- ROMANISMO CULTURAL}

No hay por qué ponderar el universalismo cristiano de san Isidoro. Era herencia sacra de los siglos anteriores que el doctor de las Españas muy bien conocía e hizo suya. Ahora bien, san Isidoro conjunta este universalismo cristiano con un nacionalismo plenamente consciente. La fusión de los godos invasores - en minoría numérica — con la masa nativa romanizada la veía como una realidad autónoma frente al imperio de Roma. Este su nacionalismo lo hace sentir san Isidoro desde las primeras líneas de su Historia de regibus gothorum. ${ }^{26}$ En ellas pondera el origen histórico de los godos, origen siempre grande para todos los nacionalistas. «El pueblo de los godos, escribe, es antiquísimo. Algunos los creen descendientes de Magog, hijo de Jafet». Añade a continuación que su nombre significa «fortaleza», pues no ha habido pueblo alguno que, como él, se haya sostenido fuertemente contra Roma. Prolijo en relatar sus guerras victoriosas, ensalza a Constantino porque fue capaz de vencerlos. San Isidoro sigue aquí la pauta nacionalista de ensalzar los hechos que muestran la valía del propio pueblo.

Enemigo de la herejía arriana, san Isidoro muestra su simpatía hacia los godos, haciendo ver que se hicieron arrianos porque su rey Atanarico, habiendo ayudado en sus luchas al emperador Valente, pidió a éste enviara instructores a su pueblo para que le enseñara la fe cristiana.

Valente le envió sacerdotes arrianos que infundieron «en tan preclara gente» el error que mantuvieron durante 219 años, bien contados. Anotemos que en el relato de este hecho capital para la historia de los godos - nefasto para san Isidoro- éste los llama «gens praeclara». Da impresión de quererlos exculpar de su arrianismo. ${ }^{27}$

26 Además de la ed. en Pl., LXXXIII, col. 1057-1082: Sancti Isidori Historia Gothorum, Wandalorum et Suevorum, tenemos muy a mano la meritoria edición de C. Rodríguez Alonso, Las Historias de los Godos, Vándalos y Suevos de Isidoro de Sevilla. Estudio, edición crítica y traducción. Centro de Estudios e Investigación «San Isidoro». León 1975. (Por esta edición damos las citas del texto).

27 Las historias de los Godos, n. 7, p. 183. 
Su informe del saqueo de Roma por Alarico rezuma comprensión y disculpa frente a los truculentos relatos de la época. Ya inicialmente advierte lo que el mismo san Agustín silencia: que Alarico era cristiano de nombre, si bien profesaba la herejía. Ello explica el respeto que los godos tuvieron a los templos cristianos durante el saqueo de la ciudad —esto sí lo comenta san Agustín. Encanta lo que nos dice san Isidoro del encuentro de una virgen cristiana con un noble godo. Retenía ésta los vasos sagrados pertenecientes al culto del apóstol Pedro. «Tómalos, si te atreves», le dice la virgen cristiana al noble godo. Éste le responde de hecho y de palabra: de hecho, mandando que fuera devuelto al tesoro de san Pedro cuanto le pertenecía; de palabra, proclamando que había venido a hacer guerra a los romanos, no contra los apóstoles. ${ }^{28}$

El relato de este otro hecho histórico transpira total simpatía por el pueblo godo, que es el suyo. Nos referimos a la boda de Ataúlfo con Placidia, la hija de Teodosio y hermana de los emperadores reinantes, Arcadio y Honorio. Ya dijimos que este suceso pudo haber hecho cambiar la marcha de la historia. San Isidoro no es menos ponderativo al ver cumplido en este hecho la profecía de Daniel, quien dice que la hija del Austro habría de unirse al rey del Aquilón. ${ }^{29}$

Del segundo sucesor de Ataúlfo, Valia —el primero fue un metoro de siete días - san Isidoro anota que fue elegido por los godos para la guerra, pero que la Providencia divina lo había ordenado para la paz. La busca en el pacto que hace con el emperador Honorio, a quien devuelve su hermana, Placidia, viuda de Ataúlfo. Por sus servicios al emperador, éste le otorga la llamada Aquitania Segunda, con su capital en Tolosa. Con qué complacencia recuerda estos sucesos san Isidoro.

Cuando los días pavorosos de Atila, a quien san Isidoro llama en su providencialismo «virga furoris Dei», los godos combaten para lograr su derrota. Choca, con todo, lo poco que san Isidoro pondera tan gran suceso. Por el contrario, comenta detenidamente el intento del emperador Justiniano por intervenir en España. Lo llamó Atanagildo contra su contrincante Agila. Con pena anota san Isidoro que Atanagildo no pudo expulsar de España las tropas enviadas por Justiniano, pero que con ellas se ha entablado combate. Y ahora - se refiere a sus días - han sido aniquiladas, terminando el parcial dominio bizantino en España. Es digno de notarse que en pos de estas tropas se hallaba el gran Imperio romano, que todavía en Oriente se mantenía firme. En la visión nacionalista de san Isidoro, este imperio ya no se imponía en la estructuración política de su momento histórico. Idéntico nacionalismo transpira el comentario a los hechos del rey Leovigildo. Los resume en este juicio histórico: «Se apoderó de gran parte de España, pues antes la nación de los godos se reducía a unos límites estrechos. Pero la impiedad [arriana] ensombreció en él la gloria de tan grandes meritos». ${ }^{30}$

Para san Isidoro, si Leovigildo es el rey que engrandeció la nación goda, su hijo Recaredo fue el rey de la paz al convertirse al catolicismo, y con él, su pueblo. Le dedica este encomio: «Fue apacible, delicado, de notable bondad, y reflejó en su rostro tan gran benevolencia y tuvo en su alma tan gran benignidad, que influía en los ánimos de todos. Incluso se atraía el cariño y afecto de los 
malos [...]. Fue tan clemente, que muchas veces exoneró al pueblo de los tributos con indulgente liberalidad». ${ }^{31}$

La conversión de Recaredo al catolicismo motiva en san Isidoro mayor responsabilidad en la política del momento. Esto le obliga a amonestar al rey Sisebuto por forzar a los judíos a que se bautizaran. Veía en este rey un celo religioso, «sed non secundum scientiam». ${ }^{32}$

Del último de los reyes godos de que hace historia, Suintila, formula un elogio que no se compagina con el fallo condenatorio del Concilio IV de Toledo. Pero, al margen de este grave problema histórico, su entusiasmo por los reyes godos hace que escriba de él: «Mereció ser llamado no sólo príncipe de los pueblos sino también padre de los pobres». A este elogio sigue un recuerdo del hijo de Suintila, asociado ya al trono de su padre. Para él se ha de pedir al que rige el cielo que, después del largo mandato de su padre, sea digno de la sucesión del reino, lo cual, manifiestamente, ya no es historia sino presente. ${ }^{33}$

Con indudable satisfacción cuenta los años del reino de los godos. Matemáticamente afirma que fueron 287. Finaliza su entusiasta historia con una recapitulación en la que en verdad «recapitula» cuantas grandezas ha creído ver en el pueblo godo. Pudiéramos resumirlas en las líneas con que concluye la obra: «Después que el príncipe Sisebuto tomó el cetro del reino, alcanzaron [los godos] tan alto grado de esplendor que llegan con la presencia de sus armas no sólo a las tierras sino al propio mar. El soldado romano, sometido, les sirve. Y ve que les sirven muchos pueblos y la propia España». ${ }^{34}$

Junto con este testimonio del nacionalismo de san Isidoro que terminamos de leer en su Historia, es obligatorio comentar el prefacio inicial a la misma, que ha creado un histórico género literario: Laudes Hispaniae. En vanguardia de estas Laudes se halla la Laus Spaniae, que prologa la Historia de regibus gothorum, objeto aquí de nuestra reflexión. Ahora, toca hacernos cargo de la Laus Spaniae.

Inicialmente, anotamos que esta Laus Spaniae, tan fuera del tiempo, al parecer, y también extraña al estilo mesurado de san Isidoro, ha suscitado muy serias dudas sobre su autenticidad. Por fortuna, la crítica ha abordado muy en serio esta cuestión histốrica y se ha declarado por la autenticidad isidoriana de la famosa Laus. ${ }^{35}$

Sobre su interpretación, hay que decir que más de un historiador ha visto en ella un eco del entusiasmo que suscitaron en los geógrafos e historiadores clásicos las bellezas físicas de España y las ríquezas de su suelo y subsuelo. En este sentido escribe un acreditado investigador del tema: «Polibio y Posidonio celebraron las riquezas ubérrimas de Lusitania y las minas abundantes de la Península; Estrabón dejó una serie de testimonios encomiásticos relativos a la Bética y otras regiones del litoral; Pomponio Mela y Marcial iniciaron los cantos en honor de España, celebrando sus riquezas, sus gentes y sus emperadores». ${ }^{36}$ Indudablemente, hay que afirmar que estas laudes auto-

\footnotetext{
31 Ibídem, n. 55, p. 267.

32 Ibídem, n. 60, pp. 272.

33 Ibídem, n. 64-65, pp. 279-281.

34 Ibídem, n. 66-70, pp. 283-287.

35 Cf. Ibídem. «Parte primera. Estudio literario. VI. La Laus Spaniae. Autenticidad. Breve estudio del fragmento», pp. 50-56.

36 Ibídem, pp. 113.
} 
rizadas influyeron en la Laus Spaniae de san Isidoro. Pero las primeras líneas de la Laus ponen en evidencia la tesis isidoriana y el enmarque geográfico que da a la misma. Éstas son las primeras palabras de la Laus: «Tú eres sagrada, oh España, y madre feliz de príncipes y de pueblos». De esta manera enuncia san Isidoro su tesis, centro de convergencia de toda la Laus. Le da este enmarque geográfico: «La más hermosa de todas las tierras que se extienden desde el Occidente hasta la India». A continuación se vuelve de nuevo a la tesis para constatar: «Tú, por derecho eres ahora la reina de todas las provincias, de quien reciben prestadas sus luces no sólo el ocaso, sino también el oriente. Tú eres el honor y el ornamento del orbe y la más ilustre porción de la tierra, en la cual grandemente se goza y espléndidamente florece la gloriosa fecundidad de la nación goda». Consiste, pues, la gloria de España, no en su geografía o en su clima, sino en la gloriosa fecundidad de sus hombres. Tales hombres merecían un digno habitáculo. En estos términos lo narra san Isidoro: «Con justicia te enriqueció y fue contigo más indulgente la Naturaleza con la abundancia de todas las cosas creadas. Tú eres rica en frutos, copiosa en uvas, alegre en cosechas [...]». No es cosa de seguir a san Isidoro en este contar las muchas mercedes materiales de que fue objeto España y que son largamente escritas en este breve trozo histórico. Mas, debemos subrayar que, ya al final de la Laus, vuelve sobre sus tesis para de nuevo declarar a España fértil en talentos y en regidores de pueblos, opulenta en laurear príncipes como dichosa en parirlos. Se atreve a finalizar su Laus con un hálito de sano erotismo conyugal: «La floreciente nación de los godos te raptó a ti [España] para amarte y gozarse contigo en seguridad y felicidad de imperio». ${ }^{37}$

Sobradamente en lo dicho se ha transparentado el nacionalismo verdaderamente consciente de san Isidoro. Ahora, como complemento y, en parte, rectificación de este nacionalismo place sobremanera comentar una histórica expresión que hallamos en el corazón de la isidoriana Laus. Dos palabras la troquelan: «aurea Roma». Al hablar del poeta Prudencio, decíamos que con esta frase de metal noble daba a entender su vinculación al histórico imperio de Roma. En contraste, lamentábamos que Orosio, en su pesimismo, más epocal que suyo propio, reiteradamente escriba «misera Roma». Ahora bien, la Roma kaurea» para Prudencio y «misera» para Orosio, vuelve a ser «aurea» para san Isidoro. Pero precisemos su desarrollo histórico para que no nos desorienten los vocablos. Cierto es que Prudencio y san Isidoro convienen en su alta estima de Roma frente al negativismo de Orosio. Mas, téngase en cuenta que si Roma es para Prudencio «aurea», imperecedera en su imperio y en su cultura, para san Isidoro sigue siendo «aurea» e imperecedera tan sólo en su cultura. Y debemos ahora añadir que, si escribió breves tratados, acuciado por su patriotismo godo, una inmensa molè de obras, en primer lugar las Etimologías, fueron escritas con el entusiasmo de un canto a la Roma cultural.

Los romanos, siempre muy inteligentes en lo práctico, no tuvieron reparo, ante la superioridad de la cultura griega, en formular por la pluma de Horacio este veredicto: «Graecia capta, ferum victorem cepit». Pudiéramos decir algo semejante ante la obra de san Isidoro: «Romania capta, ferum victorem [Gothiam] cepit». En verdad se dan la mano en san Isidoro su nacionalismo consciente, por el que se vinculó al pueblo godo, y su romanismo cultural, que dejó en herencia a los que vinieron en pos de él hasta nosotros. 
Viene a la mente la lucha de gigantes en la interpretación de la historia de España entre A. Castro y C. Sánchez Albornoz. No es cosa de repetir aquí lo ya sabido. Pero es patente que nuestra reflexión nos obliga a alinearnos con C. Sánchez Albornoz. Es mucho lo que nuestra cultura actual hispana debe a aquella cultura hispano-goda, tan cultivada por san Isidoro.

Hemos querido acercarnos a las primeras reflexiones hispanas sobre nuestra historia. Nos parece que los tres nombres, Prudencio, Orosio, san Isidoro, proyectan una estela que puede ayudar a comprender la historia de España a lo largo de los siglos hasta nuestros días. Ortega y Gasset tuvo la ocurrencia de acusar a los godos, por más civilizados que los otros bárbaros, de haber sido causa de la falta de tensión vital en nuestra agitada historia de España invertebrada. De seguro que san Isidoro no compartiría su opinión. Tampoco, de seguro, la compartirán quienes simpaticen con el contenido de este estudio. Pero esto es abrirnos a otro tema que debe quedar por ahora como programa de ulterior estudio. 